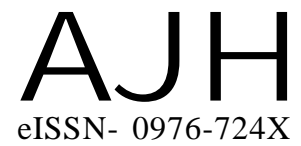

Received : 12.07.2016

Revised : 20.10.2016

Accepted : 05.11.2016

Members of the Research Forum

Associated Authors:

${ }^{1}$ Department of Fruit Science, College of Horticulture and Forestry,

Central Agricultural University, PASIGHAT (A.P.) INDIA

Email : lobsang1974@gmail.com;

chfdeanpsg@yahoo.com

${ }^{2}$ College of Horticulture and Forestry, Central Agricultural University, PASIGHAT (A.P.) INDIA

Author for correspondence :

S.R. SINGH

Department of Fruit Science, College of Horticulture and Forestry, Central Agricultural University, PASIGHAT

(A.P.) INDIA

Email : romensenjam@yahoo.com
THEASIAN JOURNALOF HORTICULTURE

Volume 11 | Issue 2 | December, 2016 | 319-322

Visit us -www.researchjournal.co.in

RESEARCH PAPER

DOI : 10.15740/HAS/TAJH/11.2/319-322

\title{
Low cost hydroponic seed germination technique for Rangpur lime (Citrus limonia)
}

\section{S.R. SINGH, L. WANGCHU ${ }^{1}$ AND A.K. PANDEY ${ }^{2}$}

ABSTRACT : Citrus seed being recalcitrant seed, 100 per cent germination is difficult under the field condition. In the hydroponic technique of seed germination, Rangpur Lime germination started after 13 days with the germination percentage of 98.9 per cent as compared to 21.4 per cent in the field condition which germinated after 30-35 days after sowing. This experiment proved to be cheap and better seed germination for the citrus seed, which could be used for the seed propagation for raising rootstock.

KEY WORDS : Rangpur lime, Hydroponics, Field condition, Germination

HOW TO CITE THIS ARTICLE : Singh, S.R., Wangchu, L. and Pandey, A.K. (2016). Low cost hydroponic seed germination technique for Rangpur lime (Citrus limonia). Asian J. Hort., 11(2) : 319-322, DOI : 10.15740/HAS/TAJH/11.2/319-322. 